\title{
Anti-inflammatory activity of elicited soybean (Glycine max) extract on Balb/C mice (Mus musculus) with high-fat and -fructose diet
}

\author{
FARIDA D. NUR'AINI', SRI RAHAYU', MUHAIMIN RIFA'I I, \\ ${ }^{1}$ Biology Department, Faculty of Mathematics and Natural Sciences, Brawijaya University, East Java, Indonesia \\ ${ }^{2}$ Biosystem, Brawijaya University, East Java, Indonesia
}

\begin{abstract}
Obesity causes adipocyte hypertrophy, which leads to cell death. Consequently, macrophages and lymphocytes infiltrate into the adipose tissue and elevate pro-inflammatory cytokine production through TLR activation. This study aimed to determine the efficacy of soybean extract, which was elicited by Saccharomyces cerevisiae and light, as an anti-inflammatory agent in mice with a high-fat and-fructose diet (HFFD). The elicited soybean extract (ESE) was administered orally to mice for four weeks after being given an HFFD for 20 weeks. Three different doses were used: (1) low-dose (78 $\mathrm{mg} / \mathrm{kg} \mathrm{BW);} \mathrm{(2)} \mathrm{normal} \mathrm{dose}$ $(104 \mathrm{mg} / \mathrm{kg} \mathrm{BW})$; and (3) high dose $(130 \mathrm{mg} / \mathrm{kg} \mathrm{BW})$. HFFD mice model treated with simvastatin $2.8 \mathrm{mg} / \mathrm{kg}$ $B W$ considered as drug control. After 24 weeks, the lymphocytes were isolated and the relative number of $\mathrm{CD}^{+}{ }^{+} \mathrm{TLR}^{+} \mathrm{T}, \mathrm{CD} 4^{+} T L R 4^{+} T, C D 4^{+} T N F-\alpha^{+} T$, and $C D 4^{+} I F N-\gamma^{+} T$ cells were analysed using flow cytometry. The results showed that the HFFD mouse model had an increased number of $C D 4^{+} T L R 3^{+} T$, $C D 4^{+} T L R 4^{+} T, C D 4^{+} T N F-\alpha^{+} T$, and $C D 4^{+} I F N-\gamma^{+} T$ cells. ESE administration decreased the relative number of $C D 4^{+} T L R 3^{+} T, C D 4^{+} T L R 4^{+} T, C D 4^{+} T N F-\alpha^{+} T$, and $C D 4^{+} I F N-\gamma^{+} T$ cells. The normal dose of ESE is the most effective dose in suppressing inflammation compared to positive controls. ESE $104 \mathrm{mg} / \mathrm{kg} B W$ can be considered as an alternative herbal medicine that may suppress inflammation in HFFD mice.
\end{abstract}

Key words: high fat-fructose diet, anti-inflammatory, elicited soybean extract.

(Centr Eur J Immunol 2019; 44 (1): 7-14)

\section{Introduction}

Excessive consumption of fat and fructose leads to obesity due to lipid accumulation $[1,2]$. The greater calorie intake than energy expenditure leads to accumulation of lipids in fat tissue [3]. Excessive accumulation of lipids, especially triglycerides, can cause adipocyte hypertrophy and hyperplasia [4]. Hypertrophy adipocytes are damaged and die [5] causing pro-inflammatory cytokine production by fat tissue [6]. Pro-inflammatory cytokines on fat tissue cause the infiltration of immunocompetent cells into the fat tissue, thereby triggering excessive production of pro-inflammatory cytokines $[7,8]$.

Toll-like receptor (TLR) is an inflammatory mediator that can be activated by lipopolysaccharide (LPS) and other ligands, such as danger-associated molecular pattern (DAMP) [9]. Elevating the DAMP production causes increased expression of TLR3 and TLR4, which have an inflammation mediator function [10].

Soybean (Glycine max) has the potential to eliminate the negative effect of overweight $[11,12]$. Soybean is a source of isoflavone, which in elicited soybean extract was higher than unelicited soybean extract. A recent study suggest that the combination of microorganism and light could enhance the isoflavone profile compared to microorganism alone [13]. Secondary metabolites of elicited soybean are mainly genistein, daidzein, and glyceollin [14, 15]. Genistein can cause lipolysis and prevent the adipogenesis process, thus inhibiting the formation of adipocytes [16, 17]. Glyceollin on soybean can suppress inflammation by inhibiting the activation of NF- $\kappa \mathrm{B}$, thus suppressing the increased production of pro-inflammatory cytokines [18]. Daidzein has a role in reducing plasma cholesterol levels by increasing the cholesterol metabolism in hepatocytes [19]. Based on that fact, we assumed that elicited soybean extract could be an alternative therapeutic in the future to attenuate inflammation caused by a high-fat diet.

\section{Material and methods}

\section{Elicited soybean extract (ESE) preparation}

Soybean (Glycine max) var. Anjasmoro was purchased from the Indonesian Legumes Tuber Crops Research In-

Correspondence: Muhaimin Rifa'i, Brawijaya University, J1. Veteran, Malang, 65145, Malang, Indonesia, e-mail: rifa123@ub.ac.id Submitted: 08.03.2017; Accepted: 08.06.2017 
stitute (ILETRI), Malang Regency. Soybeans were soaked in $70 \%$ alcohol for 10 minutes at room temperature then washed with sterile distilled water four times [20].

Soybeans were soaked in distilled water and placed in a dark room for a day. Soybeans were grown and inoculated with $1 \times 10^{7}$ S. cerevisiae $(7.5 \mathrm{ml}$ of suspension/100 $\mathrm{g}$ soybean) in a sterile plastic wrapped box. The box was stored at room temperature with light exposure using a bulb lamp [13]. The extraction method was done as previously described [21].

Soybeans were harvested at day 3 and washed three times using distilled water. $100 \mathrm{~g}$ of soybeans were weighed and made into a paste with $70 \%$ ethanol $(300 \mathrm{ml})$ using a blender. The blended soybean was incubated at $50^{\circ} \mathrm{C}$ for one hour. The soybean was centrifuged for 10 minutes at $4500 \mathrm{rpm}$ at room temperature. The supernatant was filtered with a $0.45 \mu \mathrm{m}$ sterile filter (BD Falcon). The alcohol content of the filtrate was evaporated with a rotary evaporator and then freeze-dried. The elicited soybean extract was then stored at $-20^{\circ} \mathrm{C}$ until use.

\section{Chemical}

Simvastatin $10 \mathrm{mg}$ was purchased from Dexa Medica (Tangerang, Indonesia). PE-conjugated rat anti-mouse TLR4, PE/Cy5-conjugated rat anti-mouse TLR3, PE-conjugated rat anti-mouse TNF- $\alpha$, and PE-Cy5 conjugated anti-mouse IFN- $\gamma$ were purchased from BioLegend ${ }^{\circledR}$ (San Diego, CA).

\section{Animals and experimental design}

A total of 28 normal neonatal Balb/C female mice, three weeks old, and weighing 10-12 g were used as a model. Mice were obtained from the Integrated Research and Testing Laboratory-Unit IV, Gadjah Mada University. The experimental procedures were approved by Brawijaya University Research Ethics Committee (Animal Care and Use Committee); serial no. 647-KEP-UB.

This study used four replications in seven treatments: (1) normal diet group (negative control); (2) HFFD group (positive control); (3) normal diet group with normal dose of ESE; (4) HFFD group with simvastatin $2.8 \mathrm{mg} / \mathrm{kg}$ BW treatment; (5) HFFD group with low dose of ESE treatment $(78 \mathrm{mg} / \mathrm{kg} \mathrm{BW})$; (6) HFFD group with normal dose (104 mg/kg BW) of ESE treatment; and (7) HFFD group with high dose of ESE treatment (130 mg/kg BW). Simvastatin and ESE were administered orally once a day for four weeks. The normal dose is the conversion of the dose applied in humans to an animal model, based on FDA (Food and Drug Administration).

\section{Fructose and high-fat diet}

The normal (ND) diet group was fed with normal feed and mineral water ad libitum. The ND was provided by PT Galaxy Science, Jember, Indonesia and consisted of
$67.27 \%$ carbohydrate, $12.73 \%$ protein, and $5.33 \%$ fat. The HFFD group were fed with high fat and fructose feed, which was modified from previous research [22]. The HFFD feed consisted of $53.46 \%$ carbohydrate, $8.57 \%$ protein, and $21.06 \%$ fat. $10 \%$ fructose solution mixed with mineral water. The diet was given for over 20 weeks [23].

\section{Isolation of lymphocytes}

Mice were dissected after four-week treatments. The rats' spleens were isolated and crushed clockwise in PBS. Lymphocyte homogenates were moved into a new propylene tube, $10 \mathrm{ml}$ of PBS was added, and then they were centrifuged at $2500 \mathrm{rpm}, 10^{\circ} \mathrm{C}$, for five minutes. The pellet was resuspended in $1 \mathrm{ml}$ of PBS, and then $5 \mu \mathrm{l}$ of it was transferred into $1.5 \mathrm{ml}$ microtubes.

\section{Antibody staining}

Pellet solution was stained with extracellular and intracellular antibodies. Fluorescein isothiocyanate (FITC)-conjugated anti-mouse CD4 and phycoerythrin (PE)-conjugated anti-mouse CD8 were used as extracellular antibodies. For extracellular staining, the pellet was resuspended in $50 \mathrm{ml}$ of antibodies in sterile PBS. Antibodies for intracellular staining were PE-Cy5-conjugated anti-mouse IFN- $\gamma$, PE-conjugated anti-mouse TNF- $\alpha$, PE-conjugated rat anti-mouse TLR3, and PE/Cy5-conjugated rat anti-mouse TLR4. Intracellular antibody staining is done by adding $50 \mathrm{ml}$ cytofix-cytosperm into pellets and then incubating for $20 \mathrm{~min}$ at $4^{\circ} \mathrm{C}$. After that, the solution was added to $500 \mathrm{ml}$ of washperm and centrifuged at $2500 \mathrm{rpm}, 4^{\circ} \mathrm{C}$, for five minutes. Furthermore, pellet and antibody solutions were resuspended in $50 \mathrm{ml}$ of sterile PBS.

\section{Flow cytometry analysis}

Cells were transferred into the cuvette and mounted on the nozzle of flow cytometer (BD FACS Calibur ${ }^{\mathrm{TM}}$ ). BD Cell Quest Pro software ${ }^{\mathrm{TM}}$ was set on the computer after that and then connected with the flow cytometer (acquiring mode). Flow cytometry analysis was conducted to determine the relative number of CD4 $4^{+} \mathrm{TLR}^{+} \mathrm{T}, \mathrm{CD} 4^{+} \mathrm{TLR} 4^{+} \mathrm{T}$, CD $4{ }^{+} \mathrm{TNF}-\alpha^{+} \mathrm{T}$, and CD4 $4^{+} \mathrm{IFN}-\gamma^{+} \mathrm{T}$ cells.

\section{Statistical analysis}

Data were analysed statistically using one-way ANOVA, parametric analysis with the significance of $0.05 \%$, and continued with Duncan test as post hoc test. SPSS version 16 for Windows was used to aid the analysis.

\section{Results}

\section{Suppression of TLR3 and TLR4 activation}

TLR is a trans-membrane protein that acts as inflammation mediator. ESE treatment in HFFD mice model is 

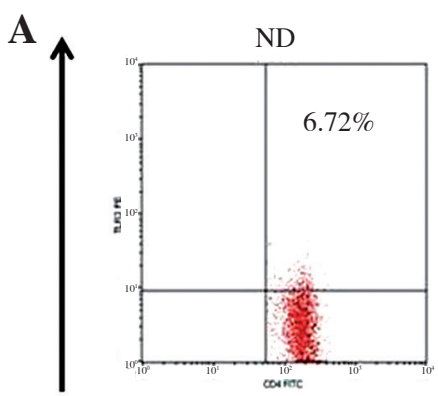

TLR3 $^{+}$

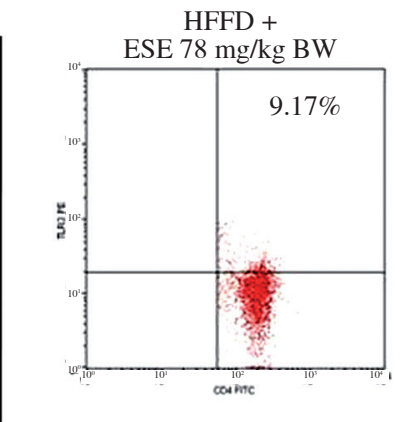

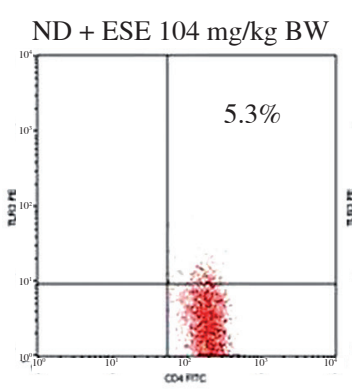

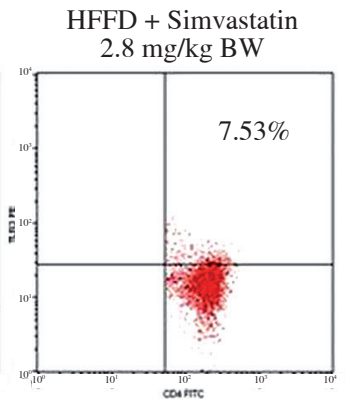

HFFD +
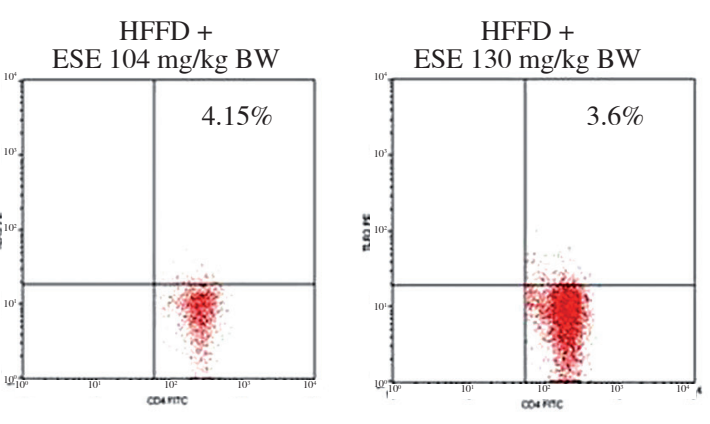

$\mathrm{CD}^{+}$

Fig. 1. Expression of TLR3 after elicited soybean extract (ESE) administration. A) Flow cytometry analysis showed the expression of TLR3 on CD4 T cells was decreased after administration with normal and high doses of ESE. B) The graph is a calculation of a relative number of $\mathrm{CD}^{+}$ $\mathrm{T}$ cells expressing TLR3 ${ }^{+} \mathrm{T}$ cells on spleen cells after ESE treatment for four weeks. Data are mean \pm SD values of each group, $p \leq 0.05$. The difference of abjad indicated a significant difference by Duncan test. D1 - ES 78 mg/kg BW (low dose), D2 - ESE 104 mg/kg BW (normal dose), D3 - EKE $130 \mathrm{mg} / \mathrm{kg} \mathrm{BW}$ (high dose), ND - normal diet, HFFD high-fat and -fructose diet, ESE - elicited soybean extract, Sim - simvastatin $2.8 \mathrm{mg} / \mathrm{kg} \mathrm{BW}$

capable of inhibiting the activation of TLR $3^{+}$in normal and high doses, compared to an untreated HFFD mouse model (Fig. 1A). TLR3 ${ }^{+}$can be activated when it binds to a ligand such as DAMP, like an mRNA of dying adipocytes under obesity conditions [11]. The relative number of $\mathrm{CD}^{+}{ }^{+} \mathrm{TLR}^{+} \mathrm{T}$ cells declines after ESE treatment at normal and high doses, which is related to the inhibition of TLR3 activation (Fig. 1B).

The results showed that ESE treatment is able to suppress TLR4 activation (Fig. 2A). All of the ESE doses can reduce the relative number of $\mathrm{CD} 4^{+} \mathrm{TLR} 4^{+} \mathrm{T}$ cells compared to untreated HFFD mice $(p<0.05)$ (Fig. 2B). The normal and high dose of ESE can decrease the relative



number of TLR $3^{+}$and TLR $4^{+}$cells significantly $(p<0.05)$ compared to the HFFD mouse model without treatment, while the low dose of ESE was only able to suppress the activation of TLR3 $3^{+}$.

\section{Inhibiting pro-inflammation cytokines}

The elevation of TLR3 and TLR4 activity in the HFFD mouse model was also followed by the increase of pro-inflammatory cytokines number as TNF- $\alpha$ and IFN- $\gamma$. Normal-diet mice had the relative number of T CD4 ${ }^{+} \mathrm{TNF}-\alpha^{+}$ at $11.63 \%$ of the T CD4 population (Fig. 3A). The average number of T CD4 $4^{+} \mathrm{TNF}-\alpha^{+}$in the HFFD mice model was higher than in the normal mice, at about $16.15 \%$ 
A
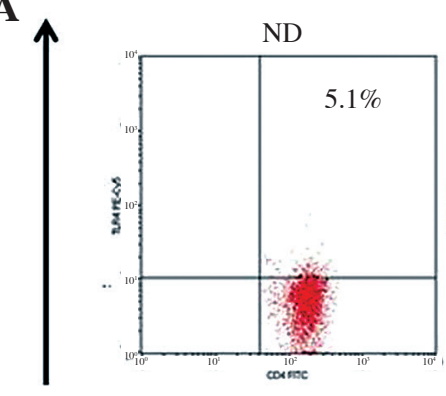

TLR4 $^{+}$
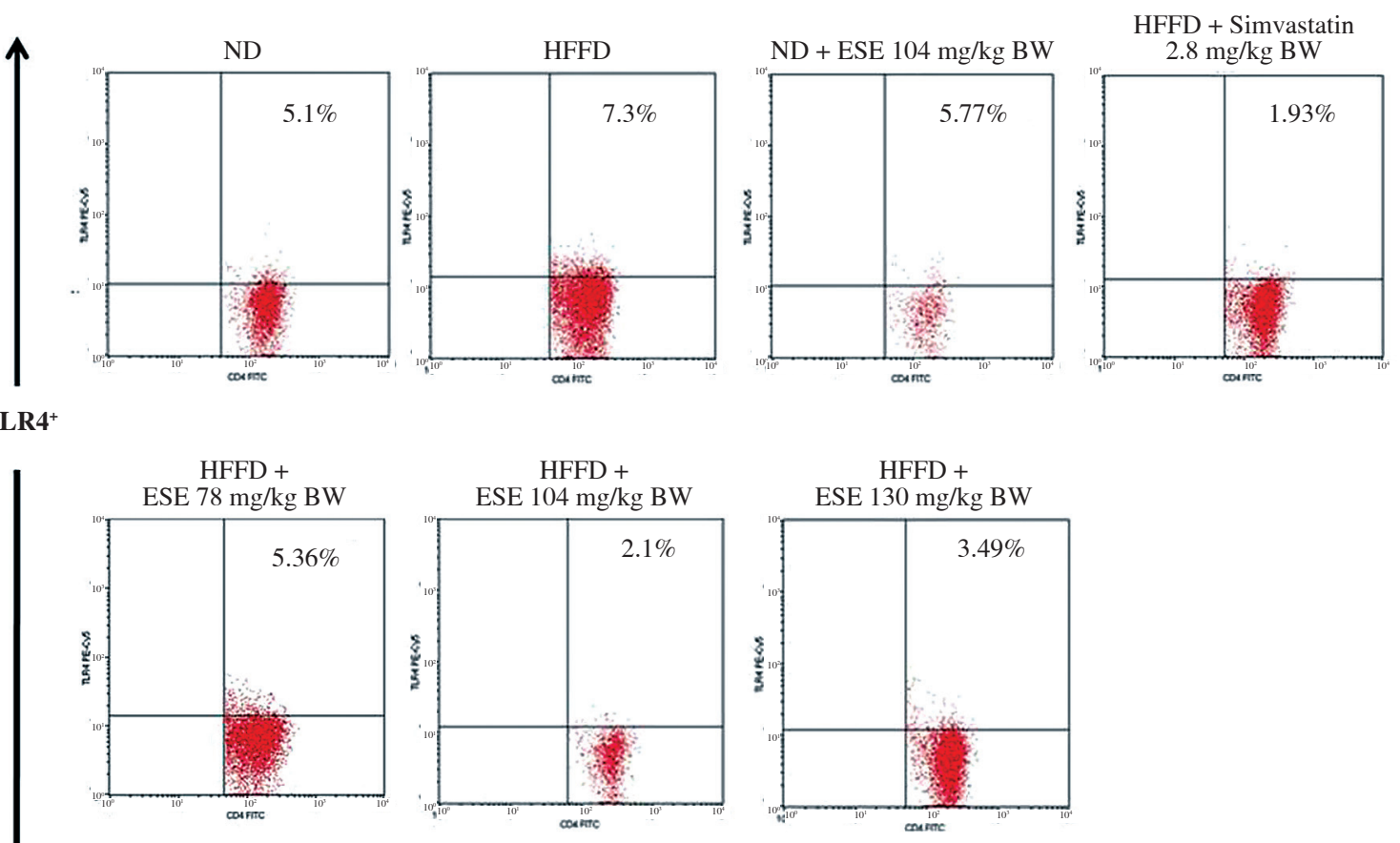

$\mathrm{CD}^{+}$

Fig. 2. Expression of TLR4 activation after elicited soybean extract (ESE) administration. A) Flow cytometry analysis showed the expression of TLR4 on CD4 T cells was decreased after administration with all doses of ESE. B) The graph is a calculation of a relative number of $\mathrm{CD}^{+}$ $\mathrm{T}$ cells expressing TLR $4^{+} \mathrm{T}$ cells on spleen cells after ESE treatment for four weeks. Data are mean \pm SD values of each group $p \leq 0.05$. The difference of abjad indicated a significant difference by Duncan test. D1 - ES $78 \mathrm{mg} / \mathrm{kg}$ BW (low dose), D2 - ESE 104 mg/kg BW (normal dose), D3 - EKE $130 \mathrm{mg} / \mathrm{kg} \mathrm{BW}$ (high dose), ND - normal diet, HFFD high-fat and -fructose diet, ESE - elicited soybean extract, Sim - simvastatin $2.8 \mathrm{mg} / \mathrm{kg} \mathrm{BW}$

of the T CD4 population of the cell. ANOVA analysis (Fig. 3B) indicated that normal-dose ESE administration can significantly reduce the expression of TNF- $\alpha$ compared to the untreated HFFD mouse model $(p<0.05)$. Simvastatin also reduced TNF- $\alpha$ expression in HFFD mice.

ESE also decrease the expression of IFN- $\gamma$ in T CD4 cells. The average number of the IFN- $\gamma$ expression in the mice with a normal diet is $12.22 \%$ of the total T CD4 population (Fig. 4A). HFFD mice had significantly increased IFN- $\gamma$ expression compared to the mice with a normal diet; up to $16.25 \%$ of the total T CD4 population. Statistical analysis suggested that (Fig. 4B) the reduced expression of IFN- $\gamma$ in the HFFD mouse model was significant at all

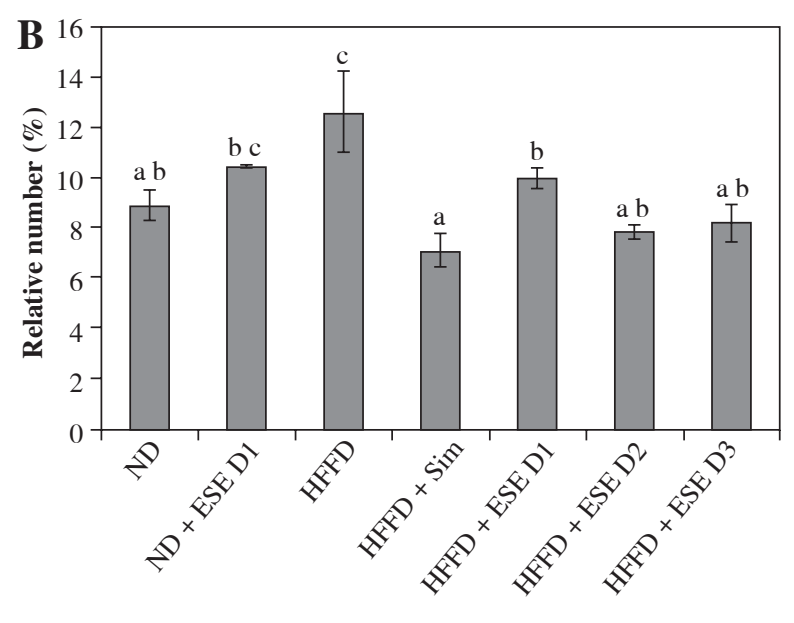

doses $(p<0.05)$. Expression of IFN- $\gamma$ in the HFFD mouse model administered with simvastatin was significantly reduced compared to the HFFD mouse model.

\section{Discussion}

Obesity is caused by an increasing amount of lipid components, primarily triglycerides, in the adipose tissues, causing adipocyte to hypertrophy and hyperplasia [4]. Hypertrophy of adipocyte leads to the death of the cell [5]. The dying adipocytes trigger an increase in adipokines including TNF- $\alpha$, IL-6, leptin, visfatin, resistin, angiotensin II, and plasminogen activator inhibitor 1 in the fat tissues [6]. 
A

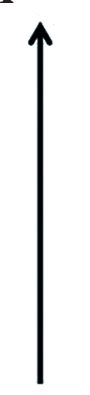

TNF- $\alpha^{+}$
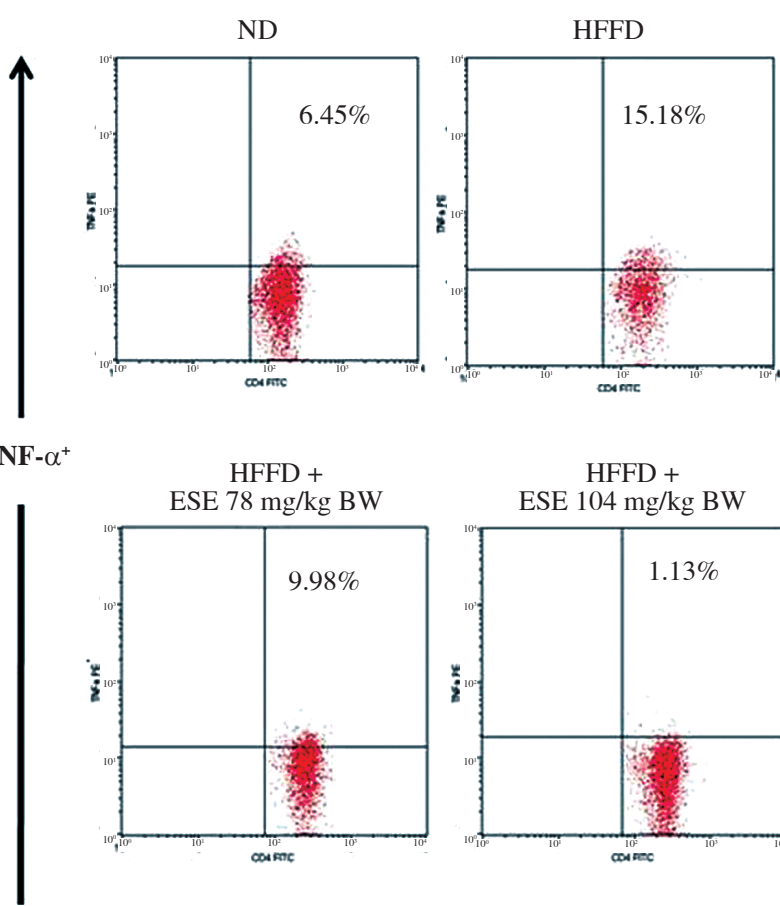

HFFD +

ESE $104 \mathrm{mg} / \mathrm{kg}$ BW



$\mathrm{ND}+\mathrm{ESE} 104 \mathrm{mg} / \mathrm{kg} \mathrm{BW}$



HFFD +

ESE $130 \mathrm{mg} / \mathrm{kg} \mathrm{BW}$

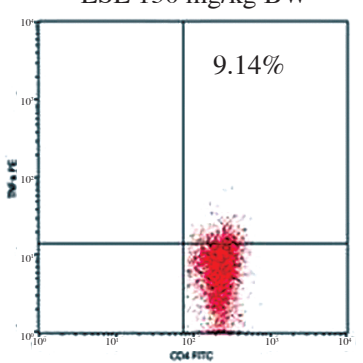

HFFD + Simvastatin $2.8 \mathrm{mg} / \mathrm{kg} \mathrm{BW}$

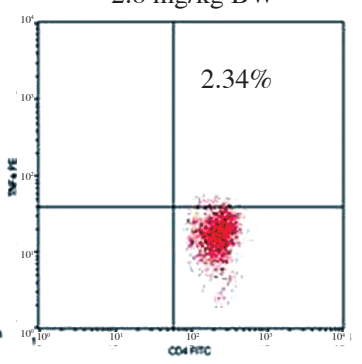

Fig. 3. The expression of TNF- $\alpha$ after elicited soybean extract (ESE) administration. A) Flow cytometry analysis showed the expression of TNF- $\alpha$ on CD4 T cells was decreased after administration with the normal dose of ESE. B) The graph is a calculation of a relative number of $\mathrm{CD}^{+} \mathrm{T}$ cells expressing TNF- $\alpha$ on spleen cells after ESE treatment for four weeks. Data are mean \pm SD values of each group $p \leq 0.05$. The difference of abjad indicated a significant difference by Duncan test. D1 - ES $78 \mathrm{mg} / \mathrm{kg}$ BW (low dose), D2 - ESE 104 mg/kg BW (normal dose), D3 - ESE 130 mg/kg BW (high dose), ND - normal diet, HFFD - high-fat and -fructose diet, ESE - elicited soybean extract, Sim - simvastatin $2.8 \mathrm{mg} / \mathrm{kg} \mathrm{BW}$

The conditions of obesity can activate TLR4 through endogenous dangerous signals (DAMP) from dying adipocytes and through the increase of fatty acid levels [10, 24]. TLR3 can also be activated once it converges with ligands, such as DAMP, which are produced by dying adipocytes under obesity conditions and eventually increase the severity of the obese condition $[10,25]$. Obese people have TNF- $\alpha$ mRNA expression two to three times higher than normal, but this will decrease with weight loss [26, 27]. IFN- $\gamma$ will increase also under obesity conditions because the activated CD4 $\mathrm{T}$ cells in the fat tissue produce more IFN- $\gamma$ than normal [28]. The increase in pro-inflammatory cytokines will worsen the inflammation, so it should be suppressed.

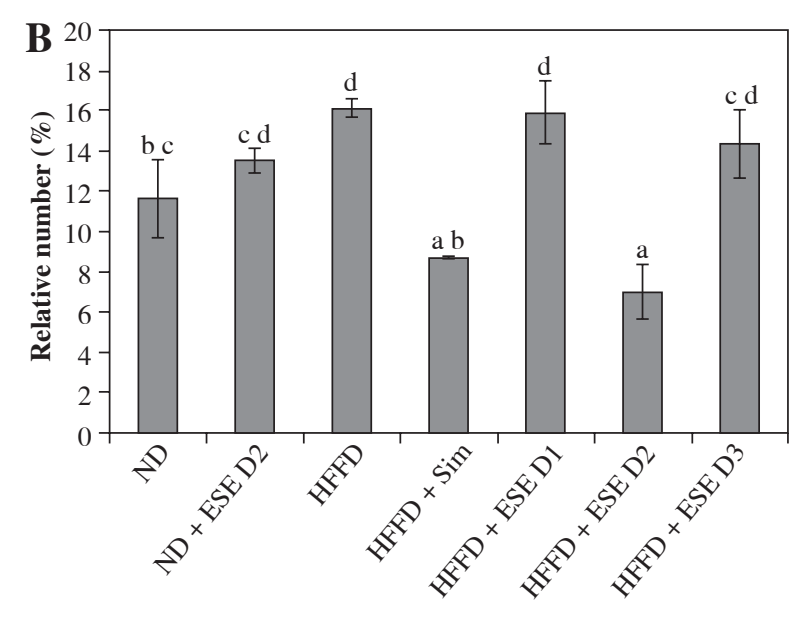

This study uses elicited soybean extracts (ESE) to suppress the inflammation that occurs in the HFFD mouse model because the content of secondary metabolites (isoflavones such as genistein, glyceollin, and daidzein) is higher than in un-elicited soybean extract [13]. Isoflavones of soybean play a role as an immunoregulator and anti-inflammatory agent [29, 30].

The results showed a significant increase in the relative number of $\mathrm{T} \mathrm{CD} 4^{+} \mathrm{TLR}^{+}$and $\mathrm{CD} 4^{+}{ }^{+} \mathrm{TLR} 4^{+}$cells in the HFFD mouse model compared to the normal diet group (Fig. 1B and Fig. 2B). The expression of TLR $3^{+}$and TLR4 ${ }^{+}$ in $\mathrm{T} \mathrm{CD} 4^{+}$cells in the HFFD mouse model were decreased after ESE administration for four weeks. Isoflavones in soy 
A

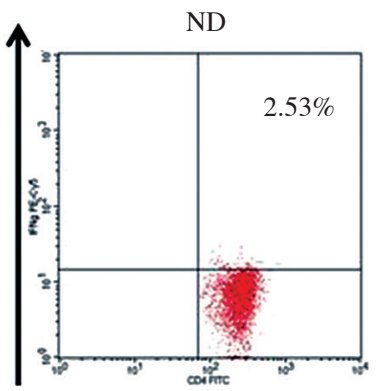

IFN- $\gamma^{+}$

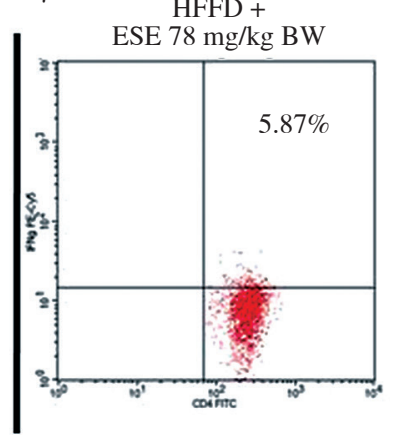

HFFD +



HFFD +

ESE $104 \mathrm{mg} / \mathrm{kg} \mathrm{BW}$

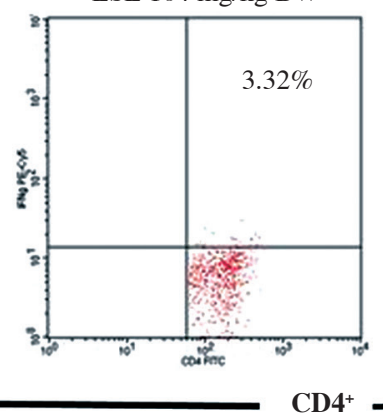

$\mathrm{ND}+\mathrm{ESE} 104 \mathrm{mg} / \mathrm{kg}$ BW

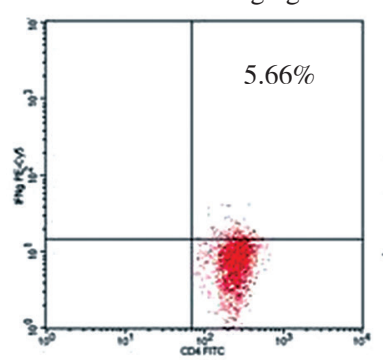

HFFD +

ESE $130 \mathrm{mg} / \mathrm{kg} \mathrm{BW}$

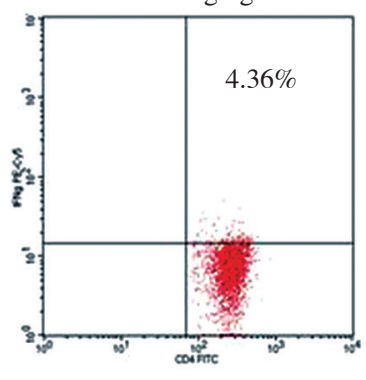

HFFD + Simvastatin $2.8 \mathrm{mg} / \mathrm{kg} \mathrm{BW}$
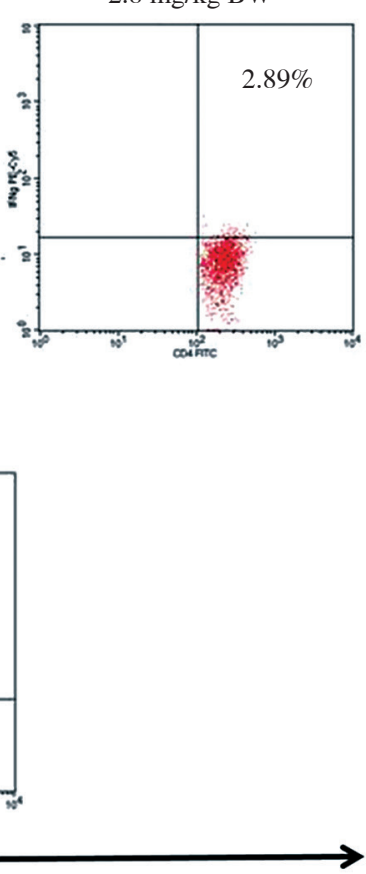

Fig. 4. The Expression of IFN- $\gamma$ after elicited soybean extract (ESE) administration. A) Flow cytometry analysis showed the expression of IFN- $\gamma$ on CD4 T cells was decreased after administration with the normal dose of ESE. B) The graph is a calculation of a relative number of $\mathrm{CD}^{+}$ T cells expressing IFN- $\gamma$ on spleen cells after ESE treatment for four weeks. Data are mean $\pm \mathrm{SD}$ values of each group $p \leq 0.05$. The difference of abjad indicated a significant difference by Duncan test. D1 - ESE $78 \mathrm{mg} / \mathrm{kg}$ BW (low dose), D2 - ESE $104 \mathrm{mg} / \mathrm{kg} \mathrm{BW}$ (normal dose), D3 - ESE 130 mg/kg BW (high dose), ND - normal diet, HFFD - high-fat and -fructose diet, ESE - elicited soybean extract, Sim - simvastatin $2.8 \mathrm{mg} / \mathrm{kg} \mathrm{BW}$

extracts may inhibit the activation of the TLR. Genistein is able to suppress inflammation induced by LPS in BV2 microglial cells by blocking the binding site between LPS and TLR4, thus inhibiting activation of NF-KB in the production of pro-inflammatory cytokines [31]. Allegedly, the genistein of ESE in this study can disrupt the bond between TLR4/TLR3 with free fatty acids or DAMP produced by dying adipocytes in the HFFD mouse model.

The results showed that a normal dose of ESE significantly decreases the production of TNF- $\alpha$ and IFN- $\gamma$ by $\mathrm{CD}^{+} \mathrm{T}$ cells in the HFFD mouse model compared to the normal-diet mice (Fig. 3B and Fig. 4B). Genistein contained in the extract acts as an inhibitor of protein tyrosine kinase, which in in vitro studies has been shown to

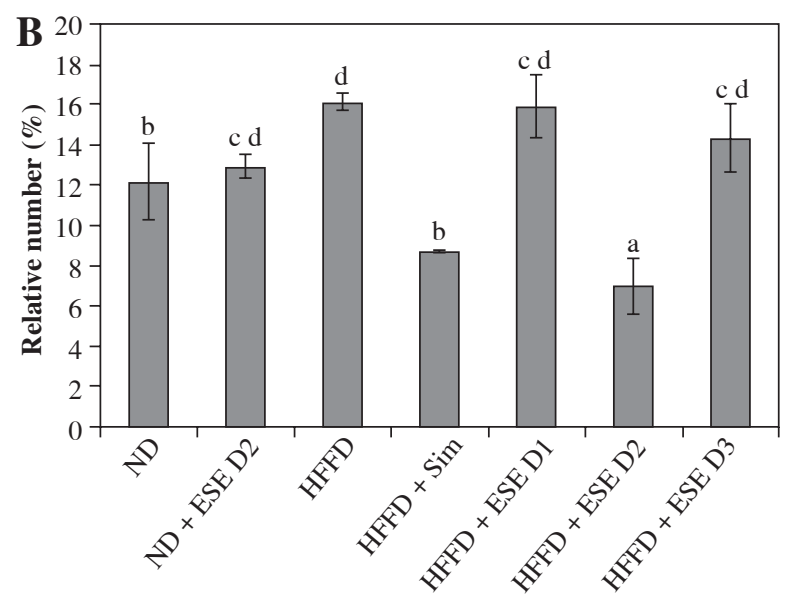

inhibit the NF- $\kappa \mathrm{B}$ 's TNF- $\alpha$ producing activity in mice with a high-fat diet [32]. In addition to being able to decrease the expression of TNF- $\alpha$, genistein is also able to reduce the production of IFN- $\gamma$ in mice encephalomyelitis after oral administration [33]. The structure of soybean's genistein is similar to $17 \beta$-oestradiol, enabling it to act like oestrogen 2 or as an antagonist to oestrogen 2, which can suppress inflammation [34].

Daidzein has been confirmed to decrease the amount of cholesterol, LDL cholesterol, and free fatty acids in the plasma and liver of mice with a high-fat diet [35]. Meanwhile, glyceollin has been found to inhibit the activity of $\mathrm{NF}-\kappa \mathrm{B}$, which plays a role in inflammation, so that the production of pro-inflammatory cytokines, such as TNF- $\alpha$ 
and IFN- $\gamma$, were also reduced [36]. Propolis is also able to suppress the production of pro-inflammatory cytokines through increased regulatory T-cell activation [37].

Administration of simvastatin with a dose of $2.8 \mathrm{mg} / \mathrm{kg}$ $\mathrm{BW}$ can decrease the expression of $\mathrm{TLR}^{+}$and TLR $4^{+}$in T CD $4^{+}$cells of the HFFD mouse model. According to [38], simvastatin is able to suppress inflammation in the adipose tissues of obese mice by inhibiting the expression of TLR3 and TLR4. Inhibition of the expression of TLR4 can suppress the activation of interferon regulatory factor (IRF) 3 , leading to inhibition of IFN- $\beta$ expression. Neutralisation of IFN- $\beta$ expression can decrease the activity of pro-inflammatory cytokines. Simvastatin reduced TNF- $\alpha$ expression, which was consistent with the previous study, which demonstrated that simvastatin can lower the mRNA expression that encodes TNF- $\alpha$ in fat tissues [39]. Simvastatin also acts as an inhibitor of IFN- $\gamma$ activation [40]. These results lead to a reduction of the risk of inflammation.

\section{Conclusions}

The elicited soybean extracts (ESE) with a normal dose $(104 \mathrm{mg} / \mathrm{kg} \mathrm{BW})$ can decrease the expression of inflammatory mediators such as TLR3 and TLR4 as well as pro-inflammatory cytokines TNF- $\alpha$ and IFN- $\gamma$. Therefore, ESE in a normal dose can be used as an alternative medicine in the treatment of obesity and as an anti-inflammatory agent.

\section{Acknowledgments}

We would thanks to Mr. Widodo for S. cerevisiae culture and all of the laboratory staff at the Physiology, Structure, and Animal Development Laboratory, Department of Biology, Faculty of Mathematic and Natural Sciences, Brawijaya University for chemicals and facilities. The authors declare there is no conflict of interest.

The authors declare no conflict of interest.

\section{References}

1. Crescenzo R, Bianco F, Coppola P, et al. (2014): Adipose tissue remodeling in rats exhibiting fructose-induced obesity. Eur J Nutr 53: 413-9.

2. Zhang Z, Wang Z, Yang Z, et al. (2015): A novel mice model of metabolic syndrome: the high-fat-high-fructose diet-fed ICR mice. Exp Anim 64: 435-442.

3. Guyton AC, Hall JE: Buku ajar fisiologi kedokteran. 11 $1^{\text {st }}$ ed. EGC. Jakarta, 2008.

4. Hausman DB, DiGirolamo M., Bartness TJ, et al. (2001): The biology of white adipocyte proliferation. Obes Rev 2: 239-254.

5. Murano I, Barbatelli G, Parisani V, et al. (2008): Dead adipocytes, detected likes crown structures, are prevalent in visceral fat depots of genetically obese mice. J Lipid Res 49: 15621568 .
6. Ouchi N, Parker J, Lugus J, et al. (2011): Adipokines in inflammation and metabolic disease. Nat Rev Immunol 11: 85-97.

7. Sun K, Kusminski CM, Scherer P (2011): Adipose tissue remodeling and obesity. J Clin Invest. 121: 2094-101.

8. Osborn O, Olefsky JM (2012): The cellular and signaling networks linking the immune system and metabolism in disease. Nat Med 18:363-74.

9. Eichacker P, Jerome P: Evolving concepts in sepsis and septic shock. Kluwer Academic Publisher. USA, 2001.

10. Ballak DB, Edwin JPA, Janna AD, et al. (2015): TLR-3 is present in human adipocytes, but its signalling is not required for obesity-induced inflammation in adipose tissue in vivo. PLoS ONE 10: e0123152.

11. Aoyama T, Fukui K, Nakamori T, et al. (2000): Effect of soy and milk whey protein isolates and their hydrolysates on weight reduction in genetically obese mice. Biosci Biotechnol Biochem 64: 2594-2600.

12. Winarsi H: protein kedelai dan kecambah, manfaatnya bagi kesehatan. Kanisius. Yogyakarta, 2010.

13. Aisyah S, Harry G, Betty M, et al. (2013): Modulation of isoflavonoid composition of rhizopus oryzae elicited soybean (Glycine max) seedlings by light and wounding. J Agric Food Chem 61: 8657-8667.

14. Feng S, Saw CL, Lee YK, et al. (2007): Fungal-stressed germination of black soybeans leads to generation of oxooctadecadienoic acids in addition to glyceollins. J Agric Food Chem 55: 8589-95.

15. Nwachukwu, Ifeanyi D, Fernando BL, et al. (2013): The inducible soybean glyceollin phytoalexins with multifunctional health-promoting properties. Food Res Int 54: 1208-1216.

16. Harmon AW, Patel YM, Harp JB (2002): Genistein inhibits CCAAT/enhancer-binding protein beta (C/EBPbeta) activity and 3T3-L1 adipogenesis by increasing C/EBP homologous protein expression. Biochem J 367: 203-8.

17. Kim HK, Nelson DC, Della FMA, et al. (2006): Genistein decreases food intake, body weight, and fat pad weight and causes adipose tissue apoptosis in ovariectomized female mice. J Nutr 136: 409-14.

18. Yoon EK, Hyun KK, Song C, et al. (2013): Soybean glyceollins mitigate inducible nitric oxide synthase and cyclooxygenase-2 expression levels via suppression of the NF-KB signaling pathway in raw 264.7 cells. J Nutr Biochem 24: 1053-1061.

19. Borradaile NM, Linda ED, Lisa JW, et al. (2002): Soya phytoestrogens, genistein and daidzein, decrease apolipoprotein B secretion from hepg2 cells through multiple mechanisms. Biochem J 366 (Pt 2): 531-539.

20. Aisyah S, Gruppen H, Andini S, et al. (2016): Variation in accumulation of isoflavonoids in phaseoleae seedlings elicited by rhizopus. Food Chem 196: 694-701.

21. Kim H J, Hwa JS, Jeong HK, et al. (2010): Antioxidant activity of glyceollins derived from soybean elicited with aspergillus sojae. J Agric Food Chem 58: 11633-11638.

22. Muthulakshmi S, Saravanan R (2013): Protective effects of azelaic acid against high-fat diet-induced oxidative stress in liver, kidney and heart of C57BL/6J mice. Mol Cell Biochem 377: 23-33.

23. Saravanan M, Perumal P, Subramaniam S, et al. (2014): Lipolytic and antiadipogenic effects of (3,3-dimethylallyl) halfordinol on 3T3-L1 adipocytes and high fat and fructose diet induced obese C57/BL6J mice. Eur J Pharmacol 740: 714-721. 
24. Jialal I, Huet BA, Kaur H, et al. (2012): Increased toll-like receptor activity in patients with metabolic syndrome. Diabetes Care 35: 900-904.

25. Jin C, Flavell RA (2013): Innate sensors of pathogen and stress: linking inflammation to obesity. J Allergy Clin Immunol 132: 287-294.

26. Kershaw EE, Jeffrey SF (2004): Adipose tissue as an endocrine organ. J Clin Endocrinol Metab 89: 2548-2556.

27. Miner JL (2004): The adipocyte as an endocrine cell. J Anim Sci 82: 935-941.

28. Pacifico L, Di RL, Anania C, et al. (2006): Increased T-helper interferon-gamma-secreting cells in obese children. Eur J Endocrinol 154: 691-697.

29. Verdrengh M, Jonsson IM, Holmdahl R, et al. (2003): Genistein as an anti-inflammatory agent. Inflamm Res 52: 341-346.

30. Masilamani M, Wei J, Sampson HA (2012): Regulation of the immune response by soybean isoflavones. Immunol Res 54 : 95-110.

31. Jeong JW, Hye HL, Han MH, et al. (2014): Anti-inflammatory effects of genistein via suppression of the toll-like receptor 4-mediated signaling pathway in lipopolysaccharide-stimulated BV2 microglia. Chem Biol Interact 212: 30-39.

32. Carter AB, Monick MM, Hunninghake GW (1998): Lipopolysaccharide-induced NF-KB activation and cytokine release in human alveolar macrophages is PKC-independent and TK- and PC-PLC-dependent. Am J Respir Cell Mol Biol 18: 384-391.

33. Jahromi SR, Seyed RA, Amir G, et al. (2014): Effect of oral genistein administration in early and late phases of allergic encephalomyelitis. Iran J Basic Med Sci 17: 509-515.

34. Sakai T, Mari K (2008): Soy isoflavones and immunity. J Med Invest 55: 167-173.

35. Guo Y, Guanzhong W, Xin S, et al. (2009): Antiobesity action of a daidzein derivative on male obese mice induced by a high-fat diet. Nutr Res 29: 656-663.

36. Park S, Ahn IS, Kim JH, et al. (2010): Glyceollins, one of the phytoalexins derived from soybeans under fungal stress, enhance insulin sensitivity and exert insulinotropic actions. J Agric Food Chem 58: 1551-1557.

37. Rifa'i M, Nashi W (2014): Significance of propolis administration for homeostasis of CD4+CD25+ immunoregulatory $\mathrm{T}$ cells controlling hyperglycemia. Springerplus $3: 526$.

38. Abe M, Morihiro M, Hironori K, et al. (2008): Effects of statins on adipose tissue inflammation. their inhibitory effect on MyD88-independent IRF3/IFN- $\beta$ pathway in macrophages. Arterioscler Thromb Vasc Biol 28: 871-877.

39. Khan T, Mark PH, Dorothy IM, et al. (2009): Impact of simvastatin on adipose tissue: pleiotropic effects in vivo. Endocrinology 150: 5262-5272.

40. Lee CS, Yong JS, Cheolhee W, et al. (2009): Simvastatin acts as an inhibitor of interferon gamma-induced cycloxygenase-2 expression in human THP-1 cells, but not in murine RAW264.7 cells. Biocell 33: 107-114. 